\title{
Síndrome do Intestino Curto: Uma Entidade de Gestão Complexa - A Propósito de um Caso Clínico e Revisão da Literatura
}

\section{Short Bowel Syndrome: A Complex Management Condition - A Case Report and Literature Review}

Bruno Besteiro',2 (https://orcid.org/0000-0003-0120-5561), Filipa Gomes ${ }^{1,2}$ (https://orcid.org/0000-0002-7919-2951), Sílvia Pinhão ${ }^{3}$ (https://orcid.org/0000-0002-3534-8344), Ana Filipa Amador ${ }^{4}$ (https://orcid.org/0000-0003-2410-7075), Isabel Garrido ${ }^{5}$ (https://orcid.org/0000-0002-7801-466X), Jorge Almeida ${ }^{1,2}$ (https://orcid.org/0000-0002-1337-7179)

\section{Resumo:}

A síndrome do intestino curto (SIC) é caracterizada por um estado de malabsorção de macro e micronutrientes que habitualmente se desenvolve após resseção de intestino delgado. Parece faltar uma correlação entre a quantidade de intestino ressecado e os sintomas desenvolvidos com a adaptação da estrutura e função intestinal. Reportamos o caso de um homem de 59 anos, submetido a resseção de $100 \mathrm{~cm}$ de intestino delgado tendo posteriormente desenvolvido síndrome de má absorção. Dos 95 dias de internamento hospitalar, várias complicações associadas à SIC ocorreram e de difícil gestão. Apesar de ser expectável um mau prognóstico, o doente apresentou melhoria significativa do estado nutricional após nutrição entérica e parentérica. À data de alta, apresentava um ganho ponderal de $9 \mathrm{~kg}$. A SIC é uma patologia pouco reportada na literatura dado tratar-se de uma entidade complexa. Pretendemos com este caso reportar todo o processo de recuperação do doente e rever a fisiopatologia desta entidade

Palavras-chave: Nutrição Entérica; Nutrição Parentérica Pseudo-Obstrução Intestinal/tratamento.

\section{Abstract:}

Short bowel syndrome (SBS) is characterized by a state of macro and micronutrient malabsorption which usually develops after small bowel resection. There is a weakly correlation between the amount of resected intestine and the clinical symptoms with the adaptation of bowel structure and function. We report a case of a 59-year-old man, who

${ }^{1}$ Serviço de Medicina Interna, Centro Hospitalar e Universitário de São João, Porto, Portugal

Departamento de Medicina, Faculdade de Medicina da

Universidade do Porto, Porto, Portugal

${ }^{3}$ Faculdade de Ciências de Nutrição e alimentação da Universidade do Porto, Porto, Portugal

${ }^{4}$ Serviço de Cardiologia, Centro Hospitalar e Universitário de São João, Porto, Portugal

${ }^{5}$ Serviço de Gastrenterologia, Centro Hospitalar e Universitário de São João, Porto, Portugal

DOI: 10.24950/CC/286/20/1/2021 underwent a $100 \mathrm{~cm}$ small bowel resection developing malabsorption syndrome afterwards. Throughout the 95 days spent in hospital many complications of SBS with complex management arose. Although the patient was expected to have a poor prognosis, his nutritional status improved significantly through continuous parenteral and enteral nutrition. At discharge he had recovered carrying a $9 \mathrm{~kg}$ weight gain. $\mathrm{SBS}$ is a non-common disease reported in the literature as being a complex entity. The aim of this case is to report the process of the patient's recovery and to provide a review of the physiopathology of this entity.

Keywords: Enteral Nutrition; Parenteral Nutrition; Short Bowel Syndrome/therapy.

\section{Introduction}

Short bowel syndrome (SBS) is a rare disorder mainly caused by extensive intestinal surgical resection of the small intestine leading to a severe reduction of the absorptive intestinal surface. Hence, this entity can lead to severe and life-threatening complications. The management of SBS is complex and challenging and it demands a dedicated multidisciplinary team to overcome the morbimortality. ${ }^{1}$

\section{Case Report}

A 59-year-old white man was submitted to cephalic duodenopancreatectomy in addition to a $100 \mathrm{~cm}$ small bowel resection owing to a later rejected pancreatic neoplasia suspicion. Subsequently, he developed weight loss, anorexia and postprandial diarrhoea with undigested foods. These symptoms were interpreted as malabsorption syndrome (MS) and throughout the following months, several hospitalizations were necessary requiring total parenteral nutrition (TPN). Within the several endoscopic procedures with biopsies performed, no abnormalities were revealed. Eight months after, he was presented to our hospital with his aggravated clinical condition, with a weight loss of $38 \mathrm{~kg}$ and bedridden.

On admission, body weight was $36 \mathrm{~kg}$ with a body mass index of $12.0 \mathrm{~kg} / \mathrm{m}^{2}$. He was noticeably pale, cachexic, with 
mucosal dryness, multiple bruises and bilateral pretibial oedema. He had no travel history, was not under any medications and there was not a dietary trigger. He undertook full laboratory tests (Table 1), including a stool test compatible with osmotic diarrhoea. Endoscopic study and computed tomography (CT) enterography were normal. There was no symptomatic improvement of dejections after ertapenem 7-day administration due to urinary tract infection. As diarrhoea stopped with enteral nutrition (EN) suspension, SBS was assumed. Once our patient was severely malnourished and it was not possible to use EN alone as he had severe diarrhoea, he was supported through low dose TPN. A slow increase in nutritional intake along with close monitoring of serum electrolytes and measurement of thiamine was made. In parallel with TPN, the early addition of small amounts of low-fat diet was started, along with multi-vitamin supplementation including folic acid and thiamine. After 48 hours full dose TPN was achieved, our patient presented

Table 1: Full laboratory results.

\begin{tabular}{|c|c|c|}
\hline & Results & Reference value \\
\hline $\begin{array}{l}\text { Hemogram } \\
\text { Hemoglobin } \\
\mathrm{MCV} \\
\mathrm{MCH} \\
\text { Leukocytes }\end{array}$ & $\begin{array}{c}5.6 \mathrm{~g} / \mathrm{dL} \\
108 \mathrm{fL} \\
34.3 \mathrm{pg} \\
6.3 \times 109 / \mathrm{L}\end{array}$ & $\begin{array}{c}13-18 \mathrm{~g} / \mathrm{dL} \\
87-103 \mathrm{fL} \\
27-35 \mathrm{pg} \\
4-11 \times 109 / \mathrm{L}\end{array}$ \\
\hline $\begin{array}{l}\text { Platelets } \\
\text { Platelet count }\end{array}$ & $83 \times 10^{9} / L$ & $150-400 \times 10^{9} / \mathrm{L}$ \\
\hline ARC & $\begin{array}{c}0.126 \times \\
10<<12>>/ L\end{array}$ & $\begin{array}{c}0.025-0.090 \times \\
10<<12>>/ L\end{array}$ \\
\hline ESR & $7 \mathrm{~mm} / 1 \mathrm{~h}$ & $0-20 \mathrm{~mm} / 1 \mathrm{~h}$ \\
\hline $\begin{array}{l}\text { Iron study } \\
\text { Serum iron } \\
\text { Serum ferritin } \\
\text { Serum transferrin }\end{array}$ & $\begin{array}{c}54 \mu \mathrm{g} / \mathrm{dL} \\
2463.3 \mathrm{ng} / \mathrm{mL} \\
<75 \mathrm{mg} / \mathrm{dL}\end{array}$ & $\begin{array}{c}53-167 \mu \mathrm{g} / \mathrm{dL} \\
20.0-250.0 \mathrm{ng} / \mathrm{mL} \\
200-360 \mathrm{mg} / \mathrm{dL}\end{array}$ \\
\hline $\begin{array}{l}\text { Lipid panel } \\
\text { Total cholesterol } \\
\text { HDL cholesterol } \\
\text { Triglycerides }\end{array}$ & $\begin{array}{l}69 \mathrm{mg} / \mathrm{dL} \\
21 \mathrm{mg} / \mathrm{dL} \\
110 \mathrm{mg} / \mathrm{dL}\end{array}$ & $\begin{array}{l}<200 \mathrm{mg} / \mathrm{dL} \\
>60 \mathrm{mg} / \mathrm{dL} \\
<150 \mathrm{mg} / \mathrm{dL}\end{array}$ \\
\hline $\begin{array}{l}\text { Liver tests } \\
\text { Albumin } \\
\text { AST } \\
\text { ALT } \\
\text { ALP } \\
\text { GGT } \\
\text { Total bilirrubin } \\
\text { Direct bilirrubin } \\
\text { LDH } \\
\text { Pancreatic } \\
\text { enzymes } \\
\text { Serum lípase } \\
\text { Serum amílase }\end{array}$ & $\begin{array}{c}12,9 \mathrm{~g} / \mathrm{L} \\
51 \mathrm{U} / \mathrm{L} \\
54 \mathrm{U} / \mathrm{L} \\
185 \mathrm{U} / \mathrm{L} \\
73 \mathrm{U} / \mathrm{L} \\
0.50 \mathrm{mg} / \mathrm{dL} \\
0.23 \mathrm{mg} / \mathrm{dL} \\
276 \mathrm{U} / \mathrm{L} \\
\\
<3 \mathrm{U} / \mathrm{L} \\
14 \mathrm{U} / \mathrm{L}\end{array}$ & $\begin{array}{c}38-51 \mathrm{~g} / \mathrm{L} \\
10-37 \mathrm{U} / \mathrm{L} \\
10-37 \mathrm{U} / \mathrm{L} \\
30-120 \mathrm{U} / \mathrm{L} \\
10-49 \mathrm{U} / \mathrm{L} \\
<1.20 \mathrm{mg} / \mathrm{dL} \\
<0.40 \mathrm{mg} / \mathrm{dL} \\
135-225 \mathrm{U} / \mathrm{L}\end{array}$ \\
\hline $\begin{array}{l}\text { Coagulation study } \\
\text { PT } \\
\text { aPTा }\end{array}$ & $\begin{array}{l}18.9 \mathrm{~s} \\
44.9 \mathrm{~s}\end{array}$ & $\begin{array}{l}10.1-13.6 \mathrm{~s} \\
24.2-36.4 \mathrm{~s}\end{array}$ \\
\hline $\begin{array}{l}\text { Ionogram } \\
\text { Sodium } \\
\text { Potassium } \\
\text { Magnesium } \\
\text { Phosphate } \\
\text { lonized calcium }\end{array}$ & $\begin{array}{l}138 \mathrm{mEq} / \mathrm{L} \\
2.7 \mathrm{mEq} / \mathrm{L} \\
1.48 \mathrm{mEq} / \mathrm{L} \\
2.8 \mathrm{mg} / \mathrm{dL} \\
2.2 \mathrm{mEq} / \mathrm{L}\end{array}$ & $\begin{array}{c}135-145 \mathrm{mEq} / \mathrm{L} \\
3.5-5.1 \mathrm{mEq} / \mathrm{L} \\
1.55-2.05 \mathrm{mEq} / \mathrm{L} \\
2.7-4.5 \mathrm{mg} / \mathrm{dL} \\
2.26-2.64 \mathrm{mEq} / \mathrm{L}\end{array}$ \\
\hline
\end{tabular}

\begin{tabular}{|l|c|c|}
\hline & Results & Reference value \\
\hline $\begin{array}{l}\text { Renal function } \\
\text { Serum Creatinine } \\
\text { Serum Urea }\end{array}$ & $\begin{array}{c}0.54 \mathrm{mg} / \mathrm{dL} \\
25 \mathrm{mg} / \mathrm{dL}\end{array}$ & $\begin{array}{c}0.67-1.17 \mathrm{mg} / \mathrm{dL} \\
10-50 \mathrm{mg} / \mathrm{dL}\end{array}$ \\
\hline CPR & $15.5 \mathrm{mg} / \mathrm{L}$ & $<3.0 \mathrm{mg} / \mathrm{L}$ \\
\hline $\begin{array}{l}\text { Vitamin B12 } \\
\text { Folic Acid }\end{array}$ & $1611 \mathrm{pg} / \mathrm{mL}$ & $187-883 \mathrm{pg} / \mathrm{mL}$ \\
\hline Vitamin D & $2.4 \mathrm{ng} / \mathrm{mL}$ & $2.2-17.5 \mathrm{ng} / \mathrm{mL}$ \\
\hline Thyroid test & $27 \mathrm{ng} / \mathrm{mL}$ & $>30 \mathrm{ng} / \mathrm{mL}$ \\
\hline TSH & & \\
\hline T4 & & \\
\hline
\end{tabular}

Stool test

Presence of

$\begin{array}{lr}\text { leukocytes in the stool } & \text { Negative } \\ \text { Potassium } & 51 \mathrm{mEq} / \mathrm{L}\end{array}$

Sodium

Osmotic gap

Detection of fat in the

stool

Detection of

reducing substances

\begin{tabular}{c|c|} 
Stool Culture & $\begin{array}{c}\text { Negative for } \\
\text { Salmonella, Shigella, } \\
\text { Clostridioides difficile, } \\
\text { Campylobacter }\end{array}$ \\
\hline
\end{tabular}

Parasitology test Negative for parasites

\begin{tabular}{l|l|}
$\begin{array}{l}\text { Viral markers } \\
\text { HBV } \\
\text { HBsAg }\end{array}$ & \\
Anti- HBC & Non reactive \\
Anti- HBs & Nonreactive \\
HCV & Positive $(640.09$ UI/L) \\
Anti-HCV & Nonreactive \\
HIV & Nonreactive \\
Treponemal tests & Negative
\end{tabular}

ALP: alkaline phosphatase; ALT: alanine transaminase; anti-HBC - hepatitis B core antibody; anti-HBs - Hepatitis B surface antibody; anti-HCV - hepatitis C antibody; aPTT: activated partial thromboplastin; ARC: absolute reticulocyte count; AST: aspartate transaminase, CPR: C-reactive protein; ESR: erythrocyte sedimentation rate; HDL: high-density lipoprotein, HIV - human immunodeficiency vírus; GGT: gamma-glutamyltransferase; HBsAg - Hepatitis B surface antigen; LDH: lactate dehydrogenase; $\mathrm{MCH}$ - mean corpuscular hemoglobina; MCV: mean corpuscular volume; PT - prothrombin time; T4: thyroxine; TSH: thyroid-stimulating hormone a Note that when the patient undertook this sample he was in food break. 
altered mental status with visual hallucination and dysmetria. A cranioencephalic-CT scan was performed excluding any abnormality. Only hypomagnesemia (1.13 mEq/L) was identified on the biochemical investigation. Hence, a clinical diagnosis of Wernicke encephalopathy secondary to re-feeding syndrome (RFS) was done. Treatment with thiamine (500 mg three times/day) and reduction of TPN dose was instituted with full recovery of the neurological symptoms one week later. At that time, every two days, the TPN dose was augmented until a full dose was achieved three weeks after. Posteriorly, a TPN dose achieving nutritional needs was administered with no complications.

During hospital stay, the patient started to tolerate larger amounts of EN supplementation using polymeric and hypolipidic enteral formula with medium-chain triglycerides (MCT), soluble fibres and maltodextrin. As there was a positive test for reducing substances, corn starch diluted in water was included in his diet. A slow but progressive clinical improvement started settling, with a total weight gain of $9 \mathrm{~kg}$ and faecal consistency improvement, allowing TPN suspension at day 75 .

When discharged, on hospital day 95, the patient weighted $45.2 \mathrm{~kg}$, he was able to walk and displayed improvement of clinical and biochemical findings. He was consuming a high energy, low-fat diet with food supplements adjusted to his preferences (including eggs white with sugar to improve serum albumin), and enteral nutritional supplements with MCT. To prevent clinical relapse and ensure continuous weight gain at home, a personalized nutritional plan was elaborated consisting of $2500 \mathrm{kcal}$, distributed into $20 \%$ of protein, $20 \%$ of lipids using MCT oil and $60 \%$ of carbs, in six meals/day, supplementation with maltodextrin (285 $\mathrm{kcal} /$ day) to achieve the energetic needs, and soluble fibre to regulate bowel function. Table 2 describes the parenteral and enteral support over time in more detail (kilocalorie along with protein and non-protein intake dosage). At the patient's six-month follow-up visit he had put on a $12 \mathrm{~kg}$ weight gain (Fig. 1 and Table 3) and was maintaining a good nutritional state. One year after, his weight was steady, he was able to drive and no intercurrences were registered.

\section{Discussion}

SBS is a disabling malabsorptive condition whose definition is more accurately based upon intestinal dysfunction, such as a significant malabsorption of both macro and micronutrients. In its initial phases, after bowel resection, there are four main defining determinants: intestinal resection length; ileum and ileocecal valve losses; total/partial colon loss; continuity/discontinuity of the intestines. ${ }^{2}$ The ileum exhibits a more robust adaptative response than the duodenum and jejunum. However, when these sections are involved as it happened in our case, it typically results in a more pronounced hypergastrinemia with iron, folate and other micronutrient deficiencies. ${ }^{3}$ This entity is the most common cause of intestinal failure which is defined as "a reduction of gut function below the minimum necessary for the absorption of macronutrients and/or water and electrolytes, such that intravenous supplementation is required to maintain health and/or growth". ${ }^{4}$ After intestinal resection, the intestinal adaptation begins within 24-48 hours by means of a compensatory process in the remaining bowel where structural and functional changes take place. This adjustment can take up to 2-3 years. ${ }^{5,6}$

Pertaining to management, TPN should be started once the patient is hemodynamically stable to prevent malnutrition, weight loss and negative nitrogen balance. Long

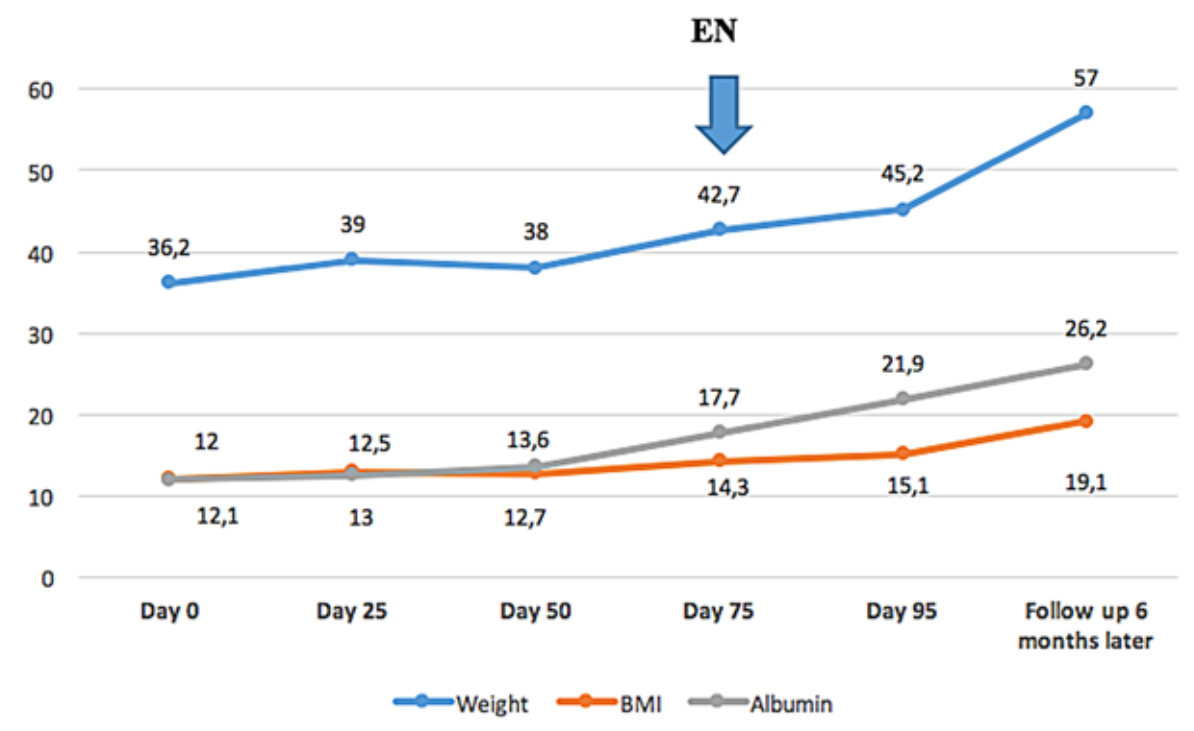

Figure 1: The patient's weight, BMI and albumin over the time. BMI, body mass index (kg/m2), EN - enteral nutrition initiation. 
Table 2: Parenteral and enteral support over time (Kcal along with protein and non-protein intake dosage).

\begin{tabular}{|c|c|c|c|}
\hline Day & Oral diet & Enteral nutrition - oral suppelements & Parenteral nutrition \\
\hline Day 2 & Bland diet (<500 kcal) & $x$ & $500 \mathrm{~mL}$ | $350 \mathrm{kcal}$ | 2 gN | $10 \mathrm{kcal} / \mathrm{kg}$ \\
\hline Day 3 & Bland diet (<500 kcal) & $x$ & 1000 mL | 650 kcal | 5 gN | 18 kcal/kg \\
\hline Day 5 & $\begin{array}{l}\text { pasty diet without fiber or residues } \\
\text { (2000 kcal) }\end{array}$ & $\begin{array}{l}\text { oligomeric nutritional supplement } \\
\text { (200 kcal / } 9 \text { g proteins) + } 50 \mathrm{~g} \text { soluble fiber }\end{array}$ & $1000 \mathrm{~mL}$ | $650 \mathrm{kcal} \mid$ | $5 \mathrm{gN} \mathrm{|} 18 \mathrm{kcal} / \mathrm{kg}$ \\
\hline Day 7 & $\begin{array}{c}\text { pasty diet without fiber or residues } \\
\text { (2000 kcal) - patient refuse to eat almost } \\
\text { diet - eat }<25 \%\end{array}$ & $\begin{array}{l}\text { oligomeric nutritional supplement } \\
\text { (200 kcal / } 9 \mathrm{~g} \text { prot) + } 50 \mathrm{~g} \text { soluble fiber } \\
\text { + MCT oil + maize starch (40 g/day) }\end{array}$ & $1320 \mathrm{~mL}$ | $901 \mathrm{kcal}$ | $6.7 \mathrm{gN}$ | $25 \mathrm{kcal} / \mathrm{kg}$ \\
\hline Day 10 & Keeps the same & Keeps the same & $493 \mathrm{~mL}$ | $518 \mathrm{kcal} \mid 2.5 \mathrm{gN}$ | $15 \mathrm{kcal} / \mathrm{kg}$ \\
\hline Day 13 & Plus appetite - eat almost 50\% & Keeps the same & $840 \mathrm{~mL}$ | $875 \mathrm{kcal}$ | $4.5 \mathrm{gN} \mathrm{|} 25 \mathrm{kcal} / \mathrm{kg}$ \\
\hline Day 18 & Keeps the same & Keeps the same & $\begin{array}{c}\text { (After re-feeding syndrome) } \\
333 \mathrm{~mL} \text { | } 350 \mathrm{kcal}|2.5 \mathrm{gN}| 10.5 \mathrm{kcal} / \mathrm{kg}\end{array}$ \\
\hline Day 20 & Keeps the same & Keeps the same & $492 \mathrm{~mL}$ | $518 \mathrm{kcal} \mid 3.7 \mathrm{gN}$ | $15 \mathrm{kcal} / \mathrm{kg}$ \\
\hline Day 23 & Keeps the same & Keeps the same & $492 \mathrm{~mL}$ | $518 \mathrm{kcal} \mid$ | $3.7 \mathrm{gN}$ | $15 \mathrm{kcal} / \mathrm{kg}$ \\
\hline Day 26 & Keeps the same & Keeps the same & $666 \mathrm{~mL}$ | $700 \mathrm{kcal} \mid 5 \mathrm{gN}$ | $20 \mathrm{kcal} / \mathrm{kg}$ \\
\hline Day 30 & Keeps the same & $\begin{array}{l}\text { oligomeric nutritional supplement 2/day } \\
\qquad(400 \mathrm{kcal}, 18 \mathrm{~g} \mathrm{P})\end{array}$ & $666 \mathrm{~mL}$ | $700 \mathrm{kcal} \mid 5 \mathrm{gN}$ | $20 \mathrm{kcal} / \mathrm{kg}$ \\
\hline Day 35 & Strats soft diet (2330 kcal) & Spots maize starch & $666 \mathrm{~mL}$ | $700 \mathrm{kcal} \mid 5 \mathrm{gN}$ | $20 \mathrm{kcal} / \mathrm{kg}$ \\
\hline Day 40 & $\begin{array}{l}\text { The same diet but without egg } \\
\text { (hyperphosphatemia) }\end{array}$ & $\begin{array}{l}\text { oligomeric nutritional supplement 3/day } \\
(600 \mathrm{kcal}, 27 \mathrm{~g} \mathrm{P})+\mathrm{MCT} \text { oil }(280 \mathrm{kcal})+ \\
\text { sweet food/desserts/cake }\end{array}$ & $999 \mathrm{~mL}$ | $1050 \mathrm{kcal}$ | $7.5 \mathrm{gN}$ | $30 \mathrm{kcal} / \mathrm{kg}$ \\
\hline Day 47 & Soft diet low fat (2000 kcal) & Keeps the same & $1500 \mathrm{~mL}$ | $1600 \mathrm{kcal} \mid 12 \mathrm{gN}$ | $45 \mathrm{kcal} / \mathrm{kg}$ \\
\hline $\begin{array}{l}\text { Day } 54 \\
\text { till } \\
\text { Day } 68\end{array}$ & Keeps the same & Keeps the same & Keeps the same \\
\hline Day 70 & Keeps the same & Keeps the same & $\begin{array}{l}\text { Peripheral access - } 1300 \mathrm{kcal} \text { | } 9.8 \mathrm{gN} \text { | } \\
37 \mathrm{kcal} / \mathrm{kg}\end{array}$ \\
\hline $\begin{array}{l}\text { Day } 75 \\
\text { till } \\
\text { Day } 95\end{array}$ & Keeps the same & Keeps the same & Stops parenteral nutrition \\
\hline $\begin{array}{l}\text { Hospital } \\
\text { discharge } \\
\text { (food plan } \\
\text { for home) }\end{array}$ & $\begin{array}{c}2500 \text { kcal. (20\%P (125 g), 20\% L (55 g), } \\
60 \% \text { Carbs (375 g)) }\end{array}$ & $\begin{array}{l}50 \mathrm{~g} \text { soluble fiber + maltodextrine } \\
\text { (75 g/285 kcal) }\end{array}$ & - \\
\hline
\end{tabular}

g-grams; gN - quantity of nitrogen in grams; Kcal - kilocalories; Kg - kilogram; L - lipis; MCT - medium-chain triglycerides; $\mathrm{mL}$ - mililiters; $\mathrm{P}$ - proteins.

term necessity depends on the four factors abovementioned. Despite TPN being crucial for the initial survival, EN should be started as soon as possible and be slowly increased depending on the stool output (primary determinant of EN tolerance). The European Society for Clinical Nutrition and Metabolism (ESPEN) guidelines state that early initiation of EN provides a better distribution and maximum exposure of the available intestinal surface-area nutrients. The continuous intake of dietary nutrients is essential to stimulate remodelling not only via direct contact with the intestinal mucosa, but also due to the release of intestinal hormones. ${ }^{7,8}$ Moreover, while a patient is under PN or EN, monitoring fluid balance and electrolytes are important measures. ${ }^{7}$ Our patient maintained TPN until day 75 , with unsuccessful weaning due to fluid/electrolyte abnormalities, food refusal, no decrease of daily dejections and other SBS related 
Table 3: Progression of laboratory findings of the patient.

\begin{tabular}{|c|c|c|c|c|c|c|c|c|c|}
\hline $\begin{array}{l}\text { Biochemical } \\
\text { parameters }\end{array}$ & $\begin{array}{l}\text { Normal } \\
\text { range }\end{array}$ & Day 10 & Day 25 & Day 40 & Day 50 & Day 55 & Day 75 & Day 95 & $\begin{array}{l}6 \text { months } \\
\text { follow-up }\end{array}$ \\
\hline $\begin{array}{l}\text { Ionized calcium } \\
(\mathrm{mEq} / \mathrm{L})\end{array}$ & $2.26-2.64$ & 2.01 & 2.3 & 2.4 & 2.3 & - & - & 2.4 & - \\
\hline $\begin{array}{c}\text { Inorganic } \\
\text { phosphorus (mg/dL) }\end{array}$ & $2.7-4.5$ & 2.6 & 3.2 & 4.6 & 4.4 & 5.3 & 4.9 & 3.8 & 3.1 \\
\hline $\begin{array}{l}\text { Serum potassium, } \\
(\mathrm{mEq} / \mathrm{L})\end{array}$ & $3.5-5.1$ & 2.8 & 4.6 & 5.6 & 4.7 & 5.3 & 3.7 & 3.6 & 4.6 \\
\hline $\begin{array}{l}\text { Serum magnesium, } \\
(\mathrm{mEq} / \mathrm{L})\end{array}$ & $1.55-2.05$ & 1.4 & 1.5 & 1.7 & - & - & - & 1.51 & 1.7 \\
\hline Hemoglobin, (g/dL) & $13.0-18.0$ & 9.5 & 7.8 & 7.4 & 7.7 & 8.1 & 9.1 & 9.9 & 12.2 \\
\hline $\begin{array}{l}\text { Platelet count } \\
\left(\times 10^{9} / \mathrm{L}\right)\end{array}$ & $150-400$ & 93 & 171 & 258 & 285 & 256 & 254 & 182 & 175 \\
\hline PT (s) & $\begin{array}{l}10, .1- \\
13.6\end{array}$ & 13.8 & 14.1 & - & - & 13.3 & - & - & - \\
\hline aPTT (s) & $24.2-36.4$ & 36.9 & 34.7 & - & - & 30.3 & - & - & - \\
\hline AST (U/L) & $10-37$ & 65 & 31 & - & - & 18 & - & 16 & 41 \\
\hline ALT (U/L) & $10-37$ & 64 & 34 & - & - & 20 & - & 22 & - \\
\hline GGT (U/L & $10-49$ & 126 & 170 & - & - & 45 & - & - & - \\
\hline ALP (U/L) & $30-120$ & 249 & 242 & - & - & 60 & - & - & - \\
\hline
\end{tabular}

Legend: ALP: alkaline phosphatase; ALT: alanine transaminase; aPTT: activated partial thromboplastin; AST: aspartate transaminase; GGT: gamma-glutamyltransferase; PT - prothrombin time

complications ahead-mentioned. Also, electrolytes and micronutrients abnormalities were corrected after targeted supplementation for each deficit. Serum levels were closely monitored at regular intervals.

When a transition to oral feeding is possible it should be done in a slow and stepwise form. If colon continuity is maintained, an hypolipidemic and rich complex carbohydrates diet is recommended. ${ }^{3}$ However, it is recommended that apart from the MCT supplementation, fat should be restricted to prevent steatorrhoea. ${ }^{7}$ In our case, MCT were preferred once they are absorbed through both small and large intestine and do not require pancreatic lipolysis. ${ }^{9}$ On the other hand, proteins typically do not entail changes in diet as nitrogen absorption is less affected by the decrease of absorptive surface in SBS. ${ }^{9}$ As recommended by ESPEN guidelines, when our patient started oral protein, the intake was divided over the day. Eggs, poultry, fish and lean minced meat are also good choices for oral provision of protein. ${ }^{7}$

SBS originate numerous acute/chronic complications. The real challenge comes from managing the multiplicity of complications. ${ }^{10}$ Systemic complications such as osteoporosis, nephrolithiasis, hepatic cholestasis and liver disease as well as D-lactic acidosis are not infrequent. ${ }^{10,11}$
RFS is a well described but often forgotten condition. It is a potentially fatal complication in malnourished patients receiving artificial nutrition. The underlying factors are metabolic and hormonal changes caused by rapid refeeding. ${ }^{11}$ It is characterized by fluid and electrolyte disturbances caused by a shift of electrolytes and vitamins from the extra-cellular space after re-feeding with glucose and aminoacids. This leads to an increased cellular uptake and dramatic depletion of phosphate, potassium, magnesium and thiamine serum levels. Hypophosphatemia is the predominant alteration. ${ }^{12}$ Diagnosis is made when clinicians come across a history of severe malnutrition, re-feeding, clinical symptoms and electrolyte abnormalities. In this case, the patient exhibited an altered mental state and associated hypomagnesemia which was coincident with an increased TPN dosage. Few case reports of SBS presenting with RFS are published in the literature. Xie $Y$ et al and Satarpia $L$ et al reported their experience in patients who were under TPN in whom Wernicke's encephalopathy developed after PN dose was increased. The biochemical findings seen were slightly hypokalaemia (3.4 mEq/L) and severe hypophosphatemia $(0.05 \mathrm{mmol} / \mathrm{L})$. In both cases, after thiamine supplementation, a complete resolution of this entity was seen. ${ }^{12,13}$ These 
reports not only demonstrate the variety of biochemical findings that may exist but also alert physicians to the risk of incorrect management of TPN and need for regular supplementation of vitamins (particularly thiamine).

After confirming that the patient's oral ingestion was stable, we have also recommended avoiding high-fat diet and maintaining a low-oxalate diet in order to prevent kidney stone formation. Calcium oxalate stones are an unpleasant complication and have been reported in $60 \%$ of patients. ${ }^{1,14}$

Diarrhoea in SBS is of multifactorial aetiology. In our case, diarrhoea was likely triggered by the absence/reduction of absorptive mucosal area, decrease in intestinal transit time and gastric hypersecretion due to parietal cell hyperplasia and hypergastrinemia which denatures pancreatic enzymes and bile salts and contributes to maldigestion/malabsorption. ${ }^{1}$ The ESPEN guidelines recommend the use of anti-diarrhoeal medication and $\mathrm{H} 2$-receptor antagonists/proton pump inhibitors to reduce the losses of water and electrolytes, faecal wet weight and to minimize the symptoms and consequences of diarrhoea. ${ }^{8}$ Antimotility therapy includes: codeine, loperamide, tincture of opium, somatostatin or octreotide and cholestyramine. ${ }^{7}$ In our case, we opted to treated our patient with 2 mg daily dosage of loperamide - to reduce intestinal motility and prolong transit time - as well as fibres and intravenous proton pump inhibitors (pantoprazole $40 \mathrm{mg}$ ) to reduce sodium excretion.

Nevertheless, it should be noted that small intestine bacterial overgrowth is able to yield these findings. Hence, this hypothesis was excluded after a negative stool test and the absence of clinical improvement with antibiotics. However, it is important to report that SBS patients who have motility disorders and who suffer from symptoms of bacterial overgrowth benefit from antibiotic treatment. ${ }^{8}$

A decreased fat-soluble vitamin absorption was assumed because these vitamins' absorption occurs in stomach and duodenum15 and our patient had coagulopathy. Although vitamin $\mathrm{K}$ deficiency is uncommon in patients with intact colon, its deficiency is frequent in patients who have taken broad-spectrum antibiotics recently, as it happened in the eight months after surgery. ${ }^{16,17}$ After supplementation of $10 \mathrm{mg}$ weekly, for 6 weeks, coagulopathy resolved.

Each nutritional program should be individualized and clinicians ought to be aware of the risks and complications, whether the nutritional support is enteral/parenteral. Although the initial survival depends on TPN, it should be followed by an aggressive attempt to use EN. Despite the few reports described, when a multidisciplinary team is present as it was in our case, a successful management with remarkable recovery is seen, even when it is not expected. ${ }^{18-20}$ Special attention must be paid towards early correction of macro and micronutrients before full dose nutritional support can be initiated.
We consider this case significant due to the scarcity of cases reported in the literature perchance justified by this entity's intricacy. This case not only epitomizes the importance of appropriate nutrition care but also highlights the importance of how a close cooperation between the medical and nutrition support can notably contribute to a favourable prognosis.

In conclusion, nutrition therapy is crucial for the successful management of SBS. Patients with this entity require lifelong monitoring and management goals frequently change over time. Despite the complexity and difficult control, treatment becomes challenging and requires patience, persistence, attention to details and appropriate multidisciplinary intervention. We expect this case could be used as an example of the management for SBS and how difficult could be to treat it.

\section{Responsabilidades Éticas}

Conflitos de Interesse: Os autores declaram a inexistência de conflitos de interesse na realização do presente trabalho.

Fontes de Financiamento: Não existiram fontes externas de financiamento para a realização deste artigo

Confidencialidade dos Dados: Os autores declaram ter seguido os protocolos da sua instituição acerca da publicação dos dados de doentes. Consentimento: Consentimento do doente para publicação obtido.

Proveniência e Revisão por Pares: Não comissionado; revisão externa por pares.

\section{Ethical Disclosures}

Conflicts of interest: The authors have no conflicts of interest to declare. Financing Support: This work has not received any contribution, grant or scholarship

Confidentiality of Data: The authors declare that they have followed the protocols of their work center on the publication of data from patients.

Patient Consent: Consent for publication was obtained.

Provenance and Peer Review: Not commissioned; externally peer reviewed.

(C) Autor (es) (ou seu (s) empregador (es)) e Revista SPMI 2021. Reutilização permitida de acordo com CC BY-NC. Nenhuma reutilização comercial. (C) Author(s) (or their employer(s)) and SPMI Journal 2021. Re-use permitted under CC BY-NC. No commercial re-use.

\section{Correspondence / Correspondência: \\ Bruno Besteiro - bruno.besteiro4@gmail.com \\ Serviço de Medicina Interna, Centro Hospitalar e Universitário de São João, Porto, Portugal \\ Alameda Prof. Hernâni Monteiro, 4200-319 Porto}

Received / Recebido: 30/11/2020

Accepted / Aceite: 25/12/2020

Publicado / Published: 15 de março de 2021 


\section{REFERENCES}

1. Parrish CR, DiBaise JK. Managing the adult patient with short bowel syndrome. Gastroenterol Hepatol. 2017;13: 600-8.

2. PB Jeppesen. Spectrum of short bowel syndrome in adults: intestinal insufficiency to intestinal failure. JPEN J Parenter Enteral Nutr.2014; 38(1 Suppl):8S-13S.

3. Seetharam P, Rodrigues Gabriel. Short bowel syndrome: a review of management options. Saudi J Gastroenterol. 2011; 17: 229-35.

4. Pironi L. Definitions of intestinal failure and the short bowel syndrome. Best Pract Res Clin Gastroenterol. 2016;30:173-85. doi: 10.1016/j. bpg.2016.02.011.

5. Drozdowski L, Thomson AB. Intestinal mucosal adaptation World J Gastroenterol. 2006; 12: 4614-27.

6. Neelis EG, Olieman JF, Hulst JM, de Koning BA, Wijnen RM, Rings EH. Promoting intestinal adaptation by nutrition and medication. Best Pract Res Clin Gastroenterol. 2016; 30:249-61.

7. Szczygiel B, Jonkers-Schuitema CF, Naber T. Basics in clinical nutrition: nutritional support in extensive gut resections (short bowel). Eur e-J Clin Nutr Metab. 2010; 5: e63-e68.

8. Pironi L, Arends J, Bozzetti F, Cuerda C, Gillanders L, Jeppesen PB, et al. Home Artificial Nutrition \& Chronic Intestinal Failure Special Interest Group of ESPEN. ESPEN guidelines on chronic intestinal failure in adults. Clin Nutr. 2016 Apr;35:247-307.

9. Kweon M, Ju DL, Park M, Choe J, Suh YS, Seol EM, et al. Intensive Nutrition Management in a Patient with Short Bowel Syndrome Who Underwent Bariatric Surgery. Clin Nutr Res. 2017;6:221-8.

10. Torres C, Vanderhoof JA. Chronic complications of short bowel syndrome.
Curr Paediatr. 2006; 16:291-7

11. Mehanna HS, Moledina J, Travis J. Refeeding syndrome: what it is, and how to prevent and treat it. BMJ. 2008; 336: 1495-8.

12. Xie Y, Zhu W, Li N, Li J. Short bowel syndrome presenting with re-feeding syndrome in a Han Chinese patient: a case report. J Med Case Rep. 2012;6:137

13. Santarpia L, Alfonsi L, Pasanisi F, Contaldo F. Wernicke's encephalopathy in a patient with short bowel syndrome on total parenteral nutrition: A case report. ESPEN J. 2009;4:e245-47.

14. Carroll RE, Benedetti E, Schowalter JP, Buchman AL. Management and Complications of Short Bowel Syndrome:an Updated Review. Curr Gastroenterol Rep. 2016;18:40.

15. Kiela PR, Ghishan FK. Physiology of Intestinal Absorption and Secretion. Best Pract Res Clin Gastroenterol. 2016;30:145-59.

16. Krzyzanowska P, Ksiazyk J, Kocielinska-Kłos M, Banas E, Kaleta M, Popinska $\mathrm{K}$, et al. Vitamin $\mathrm{K}$ status in patients with short bowel syndrome. Clin Nutr. 2012;31:1015-7.

17. Simes DC, Viegas CSB, Araújo N, Marreiros C. Vitamin K as a Diet Supplement with Impact in Human Health: Current Evidence in Age-Related Diseases. Nutrients. 2020;12:138

18. Hayes C, Khan W, Barry K. Successful management of ultra short bowel syndrome in an elderly patient. BMJ Case Rep. 2019;12:e229531.

19. Brenner CJ, Atkinson RL. Short-bowel syndrome: a case report. Nutr Rev. 1989;47:350-3.

20. Kim SJ, Kim BR, Lee SM, Kong HJ, Shin CS. Nutritional support process for a patient with short bowel syndrome in conjunction with panperitonitis: a case report. Clin Nutr Res. 2013;2:149-53. 